Journal of Animal and Feed Sciences, 7, 1998, 235 -- 239

\title{
Role of branched-chain amino acid intravenous infusion in nitrogen utilization in growing ruminants
}

\author{
J. Matras' ${ }^{1}$, R.L. Preston ${ }^{2}$ and Renata Klebaniuk ${ }^{1}$ \\ 'Institute of Animal Nutrition, Lublin Agricultural University \\ Akademicka 13, 20-932 Lublin. Poland \\ ${ }^{2}$ Department of Animal Science. Texas Tech. University \\ Lubbock, Texas 79409. USA
}

\begin{abstract}
Investigations were made of the effects on nitrogen retention of continuous intravenous infusions of branched-chain amino acids (BCAA) with glucose. Eight wether lambs $(35 \mathrm{~kg})$ fed a full feed diet (2.68 Mcal ME and $129 \mathrm{~g} \mathrm{CP} \mathrm{kg}^{-1}$, DM basis) twice daily $\left(50 \mathrm{~g} \mathrm{DM} \mathrm{W}^{-0.75} \mathrm{~d}^{-1}\right)$ at a level of 1.2 times their maintenance energy requirement were continuously infused intravenously (jugular) with L-leucine (Leu), L-isoleucine (Ile) and L-valine (Val). Infusion rates were $2.1,1.5$ and $1.7 \mathrm{~g}$ lamb $\mathrm{d}^{-1} \mathrm{~d}^{-1}$, respectively, cstimated to be about $50 \%$ of that absorbed from the gastrointestinal tract and / or required for muscle protein synthesis. Glycine was added to the infusion solutions to equalize the total $\mathrm{N}$ infused. Glucose $\left(12 \mathrm{~g} \mathrm{~W} \mathrm{~kg}^{-(0.75} \mathrm{d}^{-1}\right)$ was also supplemented in the infusion solutions to maximise $\mathrm{N}$-retention. Two $4 \times 4$ plus extra-period Latin squares were used. In square I, where the amino acids were infused individually, the treatments were: control, Leu, Ile and Val and in square II the treatments were: control, Leu, Leu + Ile and Leu + Ile + Val. Each period lasted 6 days. Digestibility coefficients of DM and OM were 75.8 and $77.1 \%$, respectively, and were not affected by the treatment. Average N-digestibility was $67.1 \%$; the Ile + Leu treatment increased N-digestibility $(\mathrm{P}<0.03)$ compared to control. None of the individually infused amino acids significantly altered urinary-N (avg. $41 \%$ of total $\mathrm{N}$-intake) or $\mathrm{N}$-balance (avg. $22 \%$ of total intake). In both squares, Leu alone failed to affect urinary-N or N-retention. Nitrogen balance was statistically $(\mathrm{P}<0.05)$ improved by $42 \%$, when Leu was infused jointly with Ile. It is concluded that Leu infusion alone does not affect $\mathrm{N}$-utilization in growing lambs, but when Leu is combined with Ile, $\mathrm{N}$-utilisation is improved. The infusion of Val had little effect on $\mathrm{N}$-utilization.
\end{abstract}

KEY WORDS: leucine, isoleucine, valine, intravenous feeding, growing shcep, nitrogen balance 
INTRODUCTION

Branched-chain amino acids (BCAA), L-leucine (Leu), L-isoleucine (Ile) and L-valine (Val), comprise about $35 \%$ of the essential amino acids in muscle protein and about $40 \%$ of the amino acids required in the diet of mammals. Since BCAA make up almost $50 \%$ of the essential amino acids in the food supply, unless the animals receive a low protein diet (Harper et al., 1984; Cronje et al., 1992), deficiencies do not generally occur. Investigations carried out in vitro with isolated tissues and perfused organs (Pösö ct al., 1982; Tischler et al., 1982), have shown however that addition of Leu increased protein synthesis and decreased protein degradation, whereas Ile and Val had little effect on protein turnover. Furthermore, in a number of studies with postoperative patients infusion of BCAA improved nitrogen $(\mathrm{N})$ balance (Freund et al., 1979, 1980). On the other hand, Harper et al. (1984) revealed that consumption of a high Leu diet by rats, ducks, pigs and turkeys resulted in retarded growth rates.

The purpose of this experiment was to study the influence of continuously infused BCAA on urinary- $\mathrm{N}$ and $\mathrm{N}$-balance in growing sheep. Infusion of these amino acids was accompanied by glucose since amino acids play a significant role in gluconeogenesis in ruminants (Bergman, 1983). Exogenous glucose diminishes endogenous gluconeogenesis in ruminants by up to 50 to $60 \%$ (Judson and Leng, 1973) and glucose infusion ( $12 \mathrm{~g}$ of glucose $\mathrm{kg}^{-0.75} \mathrm{~d}^{-1}$ ) maximally depresses urinary- $\mathrm{N}$ excretion (Matras and Preston, 1989) thus improving $\mathrm{N}$-balance. Under these conditions, it was expected that the infused BCAA would be utilized for protein synthesis rather than for gluconeogenesis and / or oxidation.

\section{MATERIAL AND METHODS}

The experiment was carried out at Texas Tech. University, Lubbock, USA. Eight Rambouillet-cross wether lambs $(35.2 \mathrm{~kg}, \mathrm{SD}=4.2)$ placed in metabolism stalls were fed twice a day a full-feed mixture, containing chopped lucerne hay, cottonseed hulls, cracked maize, cane molasses, soyabean meal and mincral-vitamin additives. The diet contained $2.68 \mathrm{Mcal}$ metabolizable energy (ME) and $129 \mathrm{~g}$ of crude protein (CP) $\mathrm{kg}^{-1} \mathrm{DM}$. The animals received the mixture in an amount of $50 \mathrm{~g}$ DM W kg ${ }^{-0.75}$ day $^{-1}$, which was an average equivalent of 1.5 times their maintenance energy requirement. Lambs were infused intravenously (jugular) according to the method described by Matras and Preston (1989). The experimental design was two $4 \times 4$ plus extra period Latin squares which estimate direct and residual effects of treatments (Lucas, 1957). The BCAA infused were L-leucine (Leu), L-isoleucine' (Ile) and L-valinc ${ }^{1}(\mathrm{Val})$. In square I the amino acids were infused

${ }^{1}$ United States Biochemical Corp., Cleveland, $\mathrm{OH} 44128$ 
TABLE 1

Experimental treatments and amino acid infusion rates, g lamb ${ }^{-1} \mathrm{~d}^{-1}$

\begin{tabular}{cll}
\hline \multirow{2}{*}{ Square } & \multicolumn{2}{c}{ Treatment } \\
\cline { 2 - 3 } & BCAA $^{\mathrm{a}}$ & amount $^{\mathrm{h}}$ \\
\hline \multirow{3}{*}{ I } & Control & - \\
& Leu & 2.1 \\
& Ile & 1.5 \\
& Val & 1.7 \\
II & Control & - \\
& Leu & 2.1 \\
& Leu + Ile & $2.1+1.5$ \\
& Leu + lle + Val & $2.1+1.5+1.7$ \\
\hline
\end{tabular}

"branched-chain amino acid; Leu $=\mathrm{L}$-leucine, Ile $=\mathrm{I}$-isoleucine, Val $=\mathrm{L}$-valine

"glycine, 3.2, 2.0, 2.3 and $1.9 \mathrm{~g} \mathrm{lamb}^{-1}$ day $^{-1}$ in control, Leu, lle and Val treatments, respectively (Square I) and 3.2, 2.0 and $1.1 \mathrm{~g} \mathrm{lamb}^{-1}$ day $^{-1}$ in Control, Leu and Leu + Ile treatments, respectively (Square II) was added to the infused solution, to equalize the total $\mathrm{N}$ infused

individually whereas in square II they were infused in combination (Table 1). The amounts of the infused amino acids were calculated to be equal to approximately $50 \%$ of that absorbed from the gastrointestinal tract and /or required for muscle protein synthesis. To equalize the total $\mathrm{N}$ infused, glycine was added to the infusion solutions. The amino acids were dissolved in sterilized saline and glucose solution. Glucose was infused at a rate of about $12 \mathrm{~g}$ glucose $\mathrm{W} \mathrm{kg}^{-0.75} \mathrm{~d}^{-1}$ (Matras and Preston, 1989).

Each infusion period lasted $6 \mathrm{~d}$; faeces and urine were collected during the last $5 \mathrm{~d}$ of each period to determine DM, organic matter (OM) and $\mathrm{N}$-digestibility coefficients, $\mathrm{N}$ excreted in the urine and $\mathrm{N}$-balance.

Each square was statistically analysed, using procedures outlined by Lucas (1957).

\section{RESULTS AND DISCUSSION}

All results and statistical comparisons are the direct effect of treatments since there were no significant residual effects.

Feed intake was constant for each lamb during the entire experiment. The intake in square I and II was: DM - 718 and $713 \mathrm{~g}$; OM - 672 and $667 \mathrm{~g} ; \mathrm{N}-14.8$ and $14.7 \mathrm{~g} \mathrm{lamb}^{-1} \mathrm{~d}^{-1}$ respectively. Average digestibility coefficients of DM and OM were 75.8 and $77.1 \%$, respectively. They were similar in both Latin squares and were not affected by the treatment. The average $\mathrm{N}$-digestibility was $67.1 \%$ and was not affected by individually infused amino acids; however, when Leu and 
TABLE 2

Influence of Leu, Ile and Val infused individually on urinary-N excretion and N-retention in growing lambs - Square I

\begin{tabular}{lccccc}
\hline ltem & \multicolumn{2}{c}{ Treatment } & SE \\
\cline { 2 - 5 } & control & Leu & Ile & Val \\
\hline N excreted in urine, g day ${ }^{\prime}$ & 6.39 & 6.79 & 6.24 & 5.93 & 0.22 \\
\% of $\mathrm{N}$ intake' & 41.0 & 43.5 & 40.0 & 38.0 & 1.40 \\
$\mathrm{~N}$ retention, $\mathrm{g}$ day ${ }^{1}$ & 3.51 & 3.08 & 3.55 & 3.73 & 0.21 \\
$\mathrm{~N}$ retention: $\mathrm{N}$ intake, $\%$ & 22.5 & 19.7 & 22.8 & 23.9 & 1.36 \\
\hline
\end{tabular}

' daily $\mathrm{N}$ intake in the diet $+\mathrm{N}$ in the infused amino acids $(14.8 \mathrm{~g}+0.6 \mathrm{~g}=15.6 \mathrm{~g})$

Ile were infused together $\mathrm{N}$-digestibility increased by about $4 \%(\mathrm{P}<0.03)$ compared to control.

Leucine infused alone did not change $(\mathrm{P}>0.05)$ the amount of $\mathrm{N}$ excreted in urine or $\mathrm{N}$ retention in growing wethers (Table 2 and 3 ). Isoleucine and Val diminished the quantity of urinary $\mathrm{N}$ excreted, primarily when added to Leu (square II), but the differences were not significant.

Neither Leu nor Ile or Val infused individually significantly changed $\mathrm{N}$ retention in lambs (Table 2). Jensen and Asplund (1979), using wether lambs (36 kg) infused intraruminally with VFA and intravenously with increasing levels of Leu, observed an improvement in N-balance with infusions of up to 4 to $6 \mathrm{~g} \mathrm{Leu} \mathrm{lamb} \mathrm{d}^{-1}$

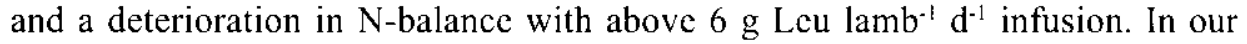
work, the infusion of $2.1 \mathrm{~g} \mathrm{lamb}^{-1}$ day $^{-1}$ in addition to an estimated $4 \mathrm{~g}$ of Leu absorbed from the gastrointestinal tract had no effect on N-balance. Although Leu or Ile infused alone did not affect protein utilization, these amino acids infused conjointly, improved $(\mathrm{P}<0.05) \mathrm{N}$-balance by $42 \%$ in comparison with control and by $31 \%$ in comparison with treatment where Leu was infused alone. Infusion of all three BCAA also improved $\mathrm{N}$-retention but not to the extent observed in Leu plus

TABLE 3

Influence of Leu, Ile and Val infused in combination on urinary $\mathrm{N}$ excretion and $\mathrm{N}$-retention in growing lambs - Square II

\begin{tabular}{|c|c|c|c|c|c|}
\hline \multirow[t]{2}{*}{ Item } & \multicolumn{4}{|c|}{ Treatment } & \multirow[t]{2}{*}{ SE } \\
\hline & control & Leu & Ile & $\mathrm{Val}$ & \\
\hline $\mathrm{N}$ excreted in urine, $\mathrm{g} \mathrm{day}^{-1}$ & 7.06 & 7.13 & 6.35 & 6.45 & 0.25 \\
\hline$\%$ of $\mathrm{N}$ intakc ${ }^{1}$ & 45.5 & 46.0 & 41.0 & 41.6 & 1.64 \\
\hline$N$ retention, $\mathrm{g} \mathrm{day}^{-1}$ & $2.75^{4}$ & $2.97^{\mathrm{a}}$ & $3.90^{\mathrm{h}}$ & $3.3^{\mathrm{ab}}$ & 0.21 \\
\hline $\mathrm{N}$ retention: $\mathrm{N}$ intake, $\%$ & $17.7^{\prime \prime}$ & $19.2^{\mathrm{i}}$ & $25.1^{\mathrm{b}}$ & $21.3^{\mathrm{ab}}$ & 1.37 \\
\hline
\end{tabular}

' daily $\mathrm{N}$ intake in the diet $+\mathrm{N}$ infused $(14.7 \mathrm{~g}+0.6 \mathrm{~g}=15.5 \mathrm{~g})$

$\mathrm{a}, \mathrm{b}=\mathrm{P}<0.05$ 
Ile treatment. These results confirm the observations of Kishi et al. (1980) who noted an improved N-balance when BCAA were infused into rats at a rate estimated to be $40 \%$ over requirement.

\section{CONCLUSIONS}

Leucine, Ile and Val infused individually with glucose did not significantly alter $\mathrm{N}$-utilization in growing lambs. However, when Leu was infused with Ile, a significant improvement in N-utilization was noted. This may indicate that these two BCAA together are limiting amino acids in growing lambs. The simultaneous infusion of glucose probably minimized the utilization of the amino acids for gluconeogenesis and reduced body protein degradation.

\section{REFERENCES}

Bergman E.N., 1983. The pools of cellular nutrients: Glucose. In: P. M. Rüs (Editor). Dynamic biochemistry of animal production. Elsevier, Department of Animal Physiology, The Royal Veterinary and Agricultural University, Copenhagen, Denmark, pp. 173-196

Cronje P.B., Nolan J.V., Leng R.A., 1992. Amino acid metabolism and whole-body protein turnover in lambs fed roughage-based diets. L-Lysine and Leucine metabolism. S. Afr. J. Anim. Sci. 22, 194-200

Freund H., Hoover H.C., Atamian J.S., Fischer J.E., 1979. Infusion of the branched chain amino acids in postoperative patients. Ann. Surg. 190, 18-23

Freund H., Yoshimura N., Fischer J.E., 1980. The role of alanine in the nitrogen conserving quality of the branched-chain amino acids in the postinjury state. J. Surg. Res. 29, 23-30

Harper A.E., Miller R.H., Block K.P., 1984. Branched-chain amino acid metabolism. Ann. Rev. Nutr. 4, 409-418

Jensen D.O., Asplund J.M., 1979. The effect of leucine infusion on various nitrogen parameters in sheep. Nutr. Rep. Int. 20, 115-123

Judson G.J., Leng R.A., 1973. Studies on the control of gluconeogenesis in sheep: effect of glucose infusion. Brit. J. Nutr. 29, 159-174

Kishi T., Iwasawa Y., Itoh H., Chibata I., 1980. Evaluation of an infusion solution enriched with branched chain amino acid in parenteral nutrition of rats. J. Nutr. 110, 710-719

Lucas H.L., 1957. Extra-period Latin-square change-over designs. J. Dairy Sci. 40, 225-239

Matras J., Preston R.L., 1989. The role of glucose infusion on the metabolism of nitrogen in ruminants. J. Anim. Sci. 67, 1642-1647

Mesbah M.M., Asplund J.M., 1984. The influence of level of valine on nitrogen status and plasma free amino acid levels in infused sheep. J. Nutr. 114, 1363-1369

Pösö A.R., Wert J.J., Mortimore G.E., 1982. Multifunctional control by amino acids of deprivationinduced proteolysis in liver. J. Biol. Chem. 257, 2114-2120

Tischler M.E., Desaultels M., Goldberg A.L., 1982. Does leucine, leucyl-tRNA, or some metabolite of leucine regulate protein synthesis and degradation in skeletal and cardiac muscle? J. Biol. Chem. 257, 1613-1621 